\title{
Breast cancer seeding in the biopsy route observed on preoperative imaging
}

\author{
Akihiro Fujimoto (1) , ${ }^{1}$ Hirofumi Yamada, ${ }^{2}$ Takahiro Hasebe, ${ }^{1}$ Toshiaki Saeki ${ }^{1}$
}

'Breast Oncology Service, Saitama Medical University International Medical Center, Hidaka, Saitama, Japan ${ }^{2}$ Kawagoe Breast Clinic, Kawagoe, Saitama, Japan

\section{Correspondence to} Akihiro Fujimoto;

afujimot@saitama-med.ac.jp

Accepted 1 June 2021

\section{DESCRIPTION}

A 71-year-old woman with an abnormality detected during the mammography screening consulted a physician. The physician palpated a mass measuring approximately $2 \mathrm{~cm}$ in the left lower outer quadrant, with no abnormal skin findings. Ultrasonography revealed an $18 \mathrm{~mm}$ hypoechoic mass with irregular margins in this region. A 12-gauge needle vacuum-assisted biopsy (VAB) (Celero; Hologic, Marlborough, MA) was performed. A puncture was made in the lower inner quadrant, approximately $5 \mathrm{~cm}$ inward from the tumour. She was diagnosed with breast cancer and presented to our hospital for treatment. On palpation (33 days postbiopsy), a new reddish nodule was observed at the puncture site with induration underneath it (figure 1). Ultrasonography (35 days) revealed a cord-like hypoechoic region from the tumour to the skin nodule, which was the biopsy route (figure 2A). Additionally, hypervascularised tissue was found around this area on colour Doppler. Imaging using 18F-fluorodeoxyglucose positron emission tomography/CT (47 days) (figure 2B) and contrast-enhanced MRI (48 days) (figure 2C) also revealed a cord-like lesion from the tumour to the skin nodule suggesting that the cancer had progressed through the biopsy route. Left mastectomy and axillary lymph node dissection were performed; the skin nodule and biopsy route were completely resected (70 days). Based on the pathological results, the patient was diagnosed with pT4bN1M0 stage IIIB invasive breast

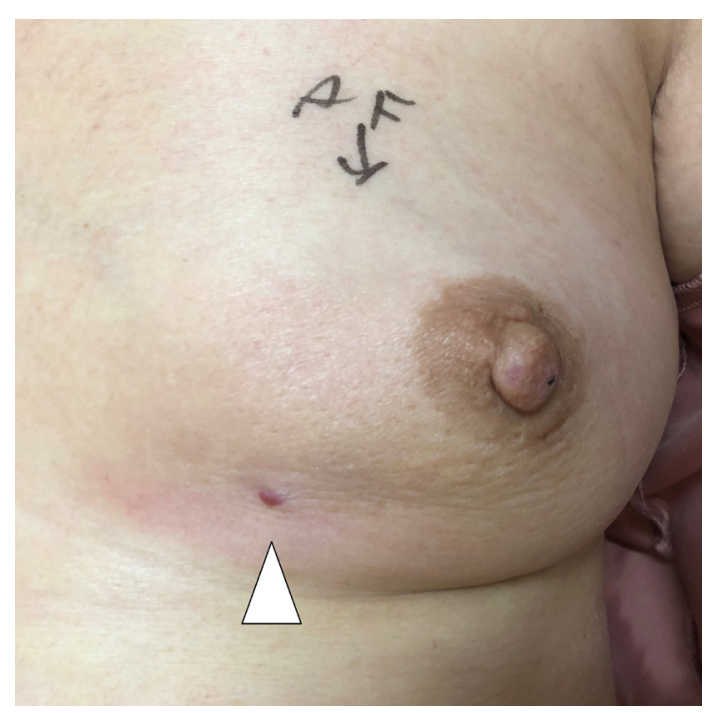

Figure 1 On palpation (33 days postbiopsy), a new reddish nodule noted on the skin at the puncture site (white arrowhead).

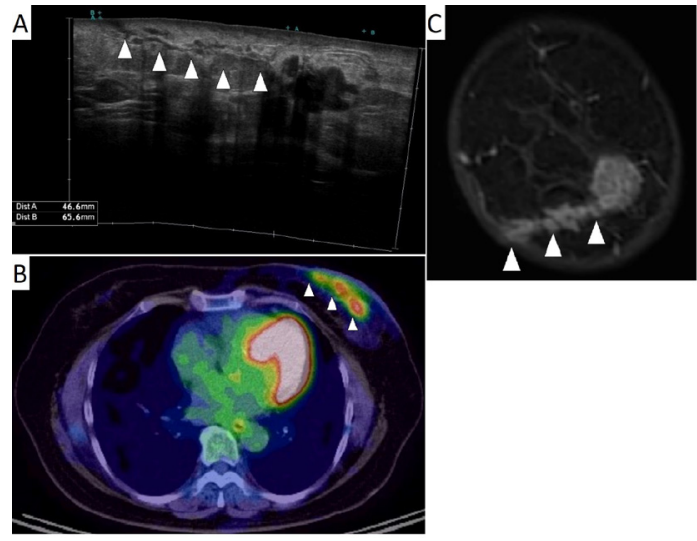

Figure 2 Ultrasonography revealing a cord-like hypoechoic region from the tumour to the skin nodule along the biopsy route (A) (arrow heads). 18Ffluorodeoxyglucose (FDG) positron emission tomography/ CT showing significant FDG uptake at the site of the cord-like lesion (B) (arrow heads). Contrast-enhanced MRI also showing an enhanced cord-like lesion in the coronal section (C) (arrow heads).

cancer. Immunohistochemical staining revealed positive expressions of oestrogen and progesterone receptors and a human epidermal growth factor receptor- 2 score of $2+$. Consistent with preoperative imaging, skin infiltrative lesions, consisting primarily of lymphatic vessel tumour emboli were found between the tumour and the skin nodule. Furthermore, the formation of cancerous lesions with dermis infiltration were observed in the skin nodule. The total infiltration diameter extended to $84 \mathrm{~mm}$. The cause was seeding associated with tumour progression that was mainly composed of lymphatic vessel tumour emboli in the biopsy route. In recent years, the treatment of cancer has become increasingly complex; moreover, it is important to collect and preserve an adequate amount of cancer tissue prior to commencing the treatment. In this case, since the patient was not at high risk of bleeding, we used VAB, which is effective in collecting a sufficient amount of tissue and is considered to be highly effective in diagnosis, instead of a core needle biopsy (CNB). VAB may not have a high frequency of seeding compared with $\mathrm{CNB}$, since $\mathrm{VAB}$ requires less punctures and produces suction pressure. ${ }^{1}$ Additionally, it has been suggested that most cancer cells displaced by a needle biopsy do not survive. ${ }^{3}$ However, VAB, which uses a larger needle than $\mathrm{CNB}$, may carry a higher risk for seeding due to the 'suckling' effect on the tumour and spread through the needle tract. 
Predicting the risk of seeding on imaging before biopsy is difficult, CNB may be safer and more recommendable in the first biopsy to avoid this rare complication. Conversely, during VAB, it is crucial to puncture from a site such that the entire biopsy route resection could be possible.

\section{Learning points}

- Tumour seeding rarely occurs in breast needle biopsies.

- This is a notable case, in which seeding in the biopsy route was observed on preoperative imaging.

- Performing the puncture from a site where the entire biopsy route can be resected is important.

Contributors Conception and design of study: AF and HY. Acquisition of data: AF and TH. Analysis and/or interpretation of data: AF and TH. Drafting the manuscript: AF. Revising the manuscript critically for important intellectual content: TH and TS. Approval of the version of the manuscript to be published: AF, $H Y$, TH and TS.
Funding The authors have not declared a specific grant for this research from any funding agency in the public, commercial or not-for-profit sectors.

Competing interests TS reports personal fees from ASKA Pharmaceutical,Astra Zeneca K.K.,Eisai, Ono Pharmaceutical, Taiho Pharmaceutical,Takeda

Pharmaceutical,Chugai Pharmaceutical, Eli Lilly Japan K.K.,Novartis Pharma

K.K.,Pfizer, MiRTeL,Meiji Seika Pharma Nippon Kayaku, grants from Eisai.,Kyowa Hakko Kirin, Taiho Pharmaceutical,Chugai Pharmaceutical,Nippon Kayaku, outside the submitted work.

Patient consent for publication Obtained.

Provenance and peer review Not commissioned; externally peer reviewed.

\section{ORCID iD}

Akihiro Fujimoto http://orcid.org/0000-0003-4261-7984

\section{REFERENCES}

1 Uematsu T, Kasami M. The use of positive core wash cytology to estimate potential risk of needle tract seeding of breast cancer: directional vacuum-assisted biopsy versus automated core needle biopsy. Breast Cancer 2010;17:61-7.

2 Loughran CF, Keeling CR. Seeding of tumour cells following breast biopsy: a literature review. Br J Radiol 2011;84:869-74.

3 Diaz LK, Wiley EL, Venta LA. Are malignant cells displaced by large-gauge needle core biopsy of the breast? AJR Am J Roentgenol 1999;173:1303-13.

Copyright 2021 BMJ Publishing Group. All rights reserved. For permission to reuse any of this content visit

https://www.bmj.com/company/products-services/rights-and-licensing/permissions/

BMJ Case Report Fellows may re-use this article for personal use and teaching without any further permission.

Become a Fellow of BMJ Case Reports today and you can:

- Submit as many cases as you like

Enjoy fast sympathetic peer review and rapid publication of accepted articles

- Access all the published articles

- Re-use any of the published material for personal use and teaching without further permission

Customer Service

If you have any further queries about your subscription, please contact our customer services team on +44 (0) 2071111105 or via email at support@bmj.com.

Visit casereports.bmj.com for more articles like this and to become a Fellow 